\title{
Geochronology and geochemistry of deep-drill-core samples from the basement of the central Tarim basin
}

\author{
Zhao-Jie Guo ${ }^{\mathrm{a}}$, An Yin ${ }^{\mathrm{b}, *}$, Alexander Robinson ${ }^{\mathrm{b}}$, Cheng-Zao Jia ${ }^{\mathrm{c}}$ \\ ${ }^{\mathrm{a}}$ Department of Geology, Peking University, Beijing 100871, China \\ ${ }^{\mathrm{b}}$ Department of Earth and Space Sciences and Institute of Geophysics and Planetary Physics, University of California, Los Angeles, CA 90095-1567, USA \\ ${ }^{\mathrm{c}}$ Petrochina Company Limited, Beijing 100011, China
}

Received 19 May 2003; revised 31 December 2003; accepted 20 January 2004

\begin{abstract}
The Tarim basin between the Tibetan plateau to the south and Tian Shan to the north in the Indo-Asian collision zone is little deformed as indicated by flat-lying Cenozoic strata across much of the basin. Due to the lack of direct observations from its crystalline basement, the geologic setting for the existence of such a rigid Cenozoic block remains elusive. Hypotheses for the nature of the Tarim basement include (1) Precambrian basement, (2) late Paleozoic trapped oceanic basin, (3) a late Precambrian failed rift, and (4) a Precambrian oceanic plateau. These models make specific predictions about the age and composition of the Tarim basement. To test these hypotheses, we conduct geochemical and geochronologic analyses of samples recovered from a deep well that reached a depth of $>7000 \mathrm{~m}$ and drilled into the crystalline basement for $\sim 35 \mathrm{~m}$ beneath the central Tarim basin. Mineralogical composition and major element analysis suggest that the crystalline from the drill core is a diorite. Under think sections the rocks samples consist of fine-grained $(0.1-0.4 \mathrm{~mm}$ in the longest dimension) and medium-grain domains (2-3 mm in the longest dimension). The contact between the two domains is sharp and the change in grain size across the boundary is abrupt. The rock under thin section shows undeformed igneous textures. Rare earth element patterns and isotopic compositions of $\mathrm{Sr}$ and $\mathrm{Nd}$ suggest that the central Tarim diorite was derived from an arc setting. The minimum age of the diorite is determined by ${ }^{40} \mathrm{Ar} /{ }^{39} \mathrm{Ar}$ dating of hornblende, which yields three ages from three different samples: 790.0 $\pm 22.1,754.4 \pm 22.6$, and $744.0 \pm 9.3 \mathrm{Ma}$, respectively (uncertainty is reported at $1 \sigma$ ). The older age is associated with the fine-grained sample while the younger ages are associated with the medium-grained samples. We are unable to determine whether the different ages are due to argon loss as the rock was located in partial retention zone or caused by different phases of igneous intrusion. In any case, the initiation of the pluton intrusion in the central Tarim region must predate $790.0 \pm 22.1 \mathrm{Ma}$. The possible existence of a Proterozoic magmatic arc $(>790 \mathrm{Ma})$ in the central Tarim region may be spatially correlated to a late Precambrian blueschist belt in the southern Tian Shan and a 970-920 Ma plutonic belt in the central and eastern Altyn Tagh range east and west of the drilling site where our samples were obtained. This regional correlation implies the existence of an east-trending Precambrian subduction system underneath the Tarim basin, which might be related to a north-dipping subduction zone. Our new data do not support the Tarim to be floored by a remnant oceanic basin or an oceanic plateau. Our results in conjunction with the fact that the Tarim interior has experienced major deformation as recent as the Jurassic do not support the hypotheses that the Tarim basement is compositionally different from and mechanically stronger than its surrounding areas during Cenozoic deformation. Differences in thermal structures or stress state could be alternative explanations for the highly inhomogeneous distribution of strain across central Asia during the Cenozoic Indo-Asian collision.
\end{abstract}

(C) 2004 Elsevier Ltd. All rights reserved.

Keywords: Tarim basin; Geochemical; Proterozoic

\section{Introduction}

The Tarim block is a prominent Cenozoic depression in central Asia (Jia et al., 1991; Li et al., 1996; Jia, 1997) (Fig. 1). The Cenozoic sedimentation has been induced by

\footnotetext{
* Corresponding author. Tel.: + 1-310-825-8752; fax: + 1-310-825-2779.

E-mail address: yin@ess.ucla.edu (A. Yin).
}

uplift and erosion of the Tian Shan in the north and the Tibetan Plateau in the south during the Indo-Asian collision (e.g. Hendrix et al., 1994; Jia, 1997; Yin et al., 1998, 2002; Yin and Harrison, 2000; Yang and Liu, 2002; Sobel et al., 2003). Understanding the geologic history of the Tarim basin has several important implications for testing regional tectonic models. With respect to the Cenozoic, it has been 


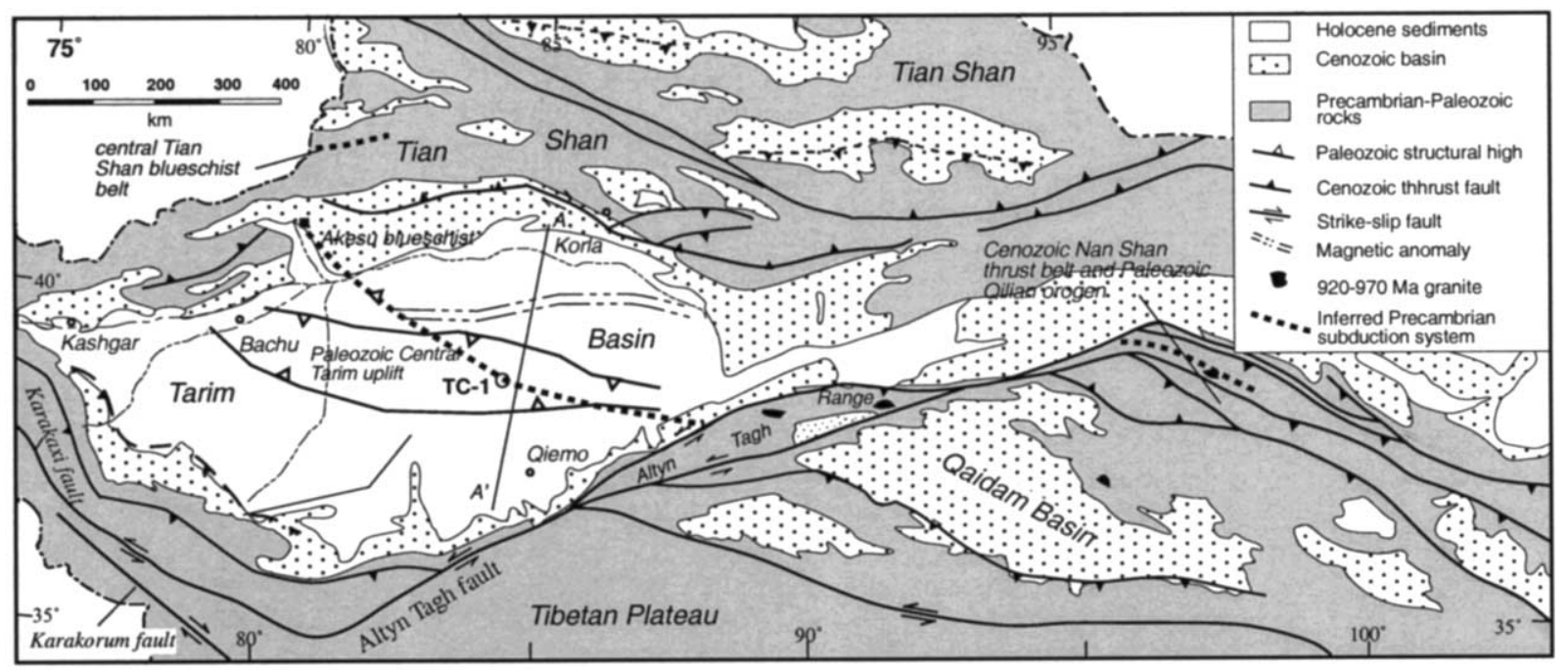

Fig. 1. Simplified tectonic map of the Tarim basin and its surrounding areas in northwest China, modified from Yin and Nie (1996). The location of the Central Tarim Geologic Survey Well (TC-1) and the magnetic anomaly pattern are also shown.

long noted that the Tarim block has experienced little Cenozoic deformation in its interior (e.g. Jia et al., 1991). Two end member views have been proposed to explain this observation. The first is that Tarim has a mechanically stronger lithosphere than its surrounding regions (e.g. Neil and Houseman, 1997). This is based the interpretation that Precambrian crystalline rocks surrounding Tarim might be projected beneath the basin (Xinjiang BGMR, 1993; Chen et al., 2003; Gehrels et al., 2003a,b) This hypothesis implies that the pre-Cenozoic crustal composition and tectonic history has played a critical role in controlling the Cenozoic deformation pattern of central Asia. Alternatively, the Tarim basin could have escaped Cenozoic deformation because of the arrangement of large-scale Cenozoic conjugate strike-slip faults (Molnar and Tapponnier, 1975). That is, the Tarim block forms a stable domain sandwiched between the two conjugate Coulomb fractures: left-slip Altyn Tagh fault in the south and the right-slip Tian Shan system in the north (Yin and Nie, 1996). This suggestion would not require the basement of the Tarim basin to be particularly stronger than its neighboring regions and that plate boundary forces and their induced intracontinental stress field are the fundamental cause of the Cenozoic tectonic pattern of Asia as originally suggested by Molnar and Tapponnier (1975) and Tapponnier and Molnar (1976).

In order to understand how the pre-Cenozoic tectonics may have controlled Cenozoic deformation of the Tarim basin, a complete understanding of its geologic history is required. The origin of the modern Tarim basin may be traced to the late Paleozoic or even farther back to the late Proterozoic. Hsü (1988) proposed that the Tarim basin is a remnant oceanic basin trapped in the broad Late Permian suture zone of the Paleo-Tethys. Alternatively, Jia et al. (1991) suggest that most of the Tarim basin was floored by a failed Proterozoic rift system. It has also been debated whether an Early Paleozoic or Precambrian suture has been offset by the Altyn Tagh fault from northwestern Tibet and extends across the central Tarim basin (Yin and Nie, 1996; Sobel and Arnaud, 1999; Guo et al., 1999).

The extremely thick late Precambrian to Phanerozoic strata, locally exceeding $15 \mathrm{~km}$, have prevented direct observations of the composition and deformational history of the Tarim basement. As a result, the tectonic interpretations are either based on inferences from surface geology from the basin margins (e.g. Xinjiang BGMR, 1993; Jia, 1997) or from geophysical data (e.g. Hsü, 1988; Tian et al., 1989; Jia et al., 1991). In the southern and central Tarim basin, magnetic surveys have revealed broad NE-trending positive anomalies alternating with relatively narrow negative anomalies (e.g. Jia et al., 1991) (Fig. 1). This pattern has been variably interpreted to represent an Archean crystalline basement (Tian et al., 1989; Wang et al., 1992), a middle Paleozoic suture (Yin and Nie, 1996), an early Mesozoic remnant back-arc basin trapped behind the Paleo-Tethyan suture (Hsü, 1988), a late Precambrianearliest Paleozoic failed rift (Jia et al., 1991), or a Neoproterozoic oceanic plateau (Sengör et al., 1996). The above models make specific predictions about the age and composition of the Tarim basement and can be tested by directly sampling the basement rocks.

To test the above competing hypotheses, we analyzed core samples recovered from a deep $(>7000 \mathrm{~m})$ geologicsurvey well during petroleum exploration of the central Tarim basin. This is the deepest well in China (Zhou et al., 2002) and is the only one in the Tarim basin that penetrated the entire sedimentary cover and reached the crystalline basement. In the following, we outline the geologic setting of the drill site and report the results of our geochronologic and geochemical analyses of the samples recovered from the drill cores. These new data suggest that the central Tarim basement is composed of a $\geq 790$-Ma diorite that lies unconformably beneath Cambrian shallow-marine strata. 
(a)

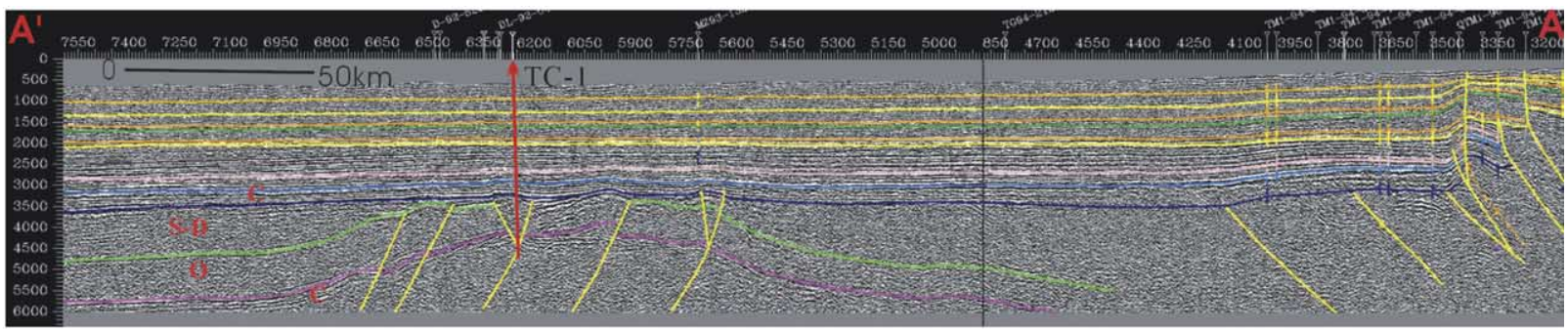

(b)

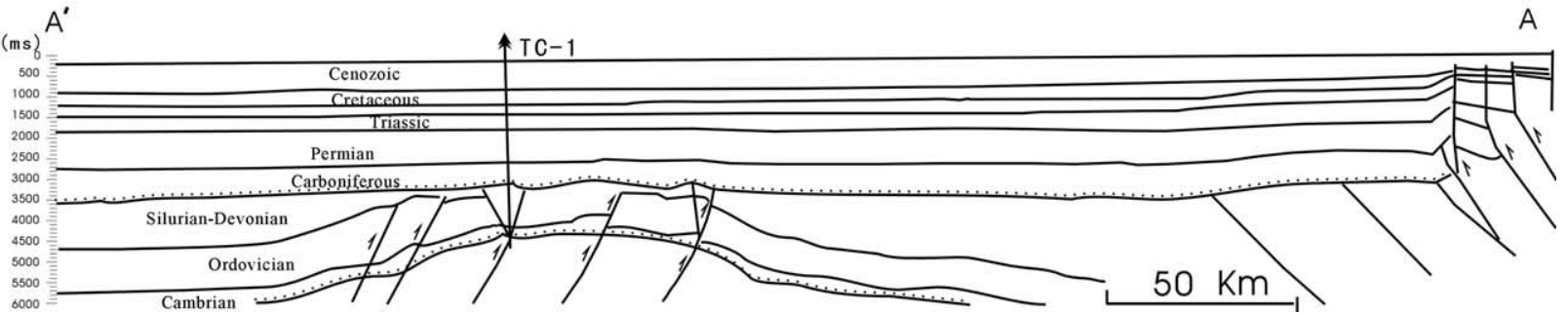

Fig. 2. (a) Composite seismic reflection profile across Tarim basin and the location of drill hole TC-1 on top of the middle Paleozoic central Tarim uplift. See Fig. 1 for location of the profile. (b) Interpreted cross section from Fig. 2a. Note that vertical scale is greatly exaggerated.

\section{Geology of the central Tarim basin}

Crystalline rocks of Precambrian basement are exposed along the southeastern margin of the eastern Tian Shan range and the northeastern margin of the Altyn Tagh range. In both places, late Precambrian shallow-marine sequences rest unconformably on top of the Precambrian basement (Xinjiang BGMR, 1993; Chen et al., 2003). Phanerozoic marine and terrestrial strata are also well preserved in the Tarim basin and have been drilled by petroleum exploration wells and imaged by seismic reflection profiles in the past several decades (Fig. 2) (Jia, 1997). Within the cover sequence above the Tarim basement there are several regionally extensive unconformities resulting from several phases of tectonic activity throughout the Phanerozoic (Jia, 1997). According to Jia (1997), major contractional deformation occurred in the Tarim interior as recent as the Triassic. In the central Tarim basin, a major unconformity is present between flat-lying Carboniferous strata above and folded and faulted Cambrian to Devonian strata below
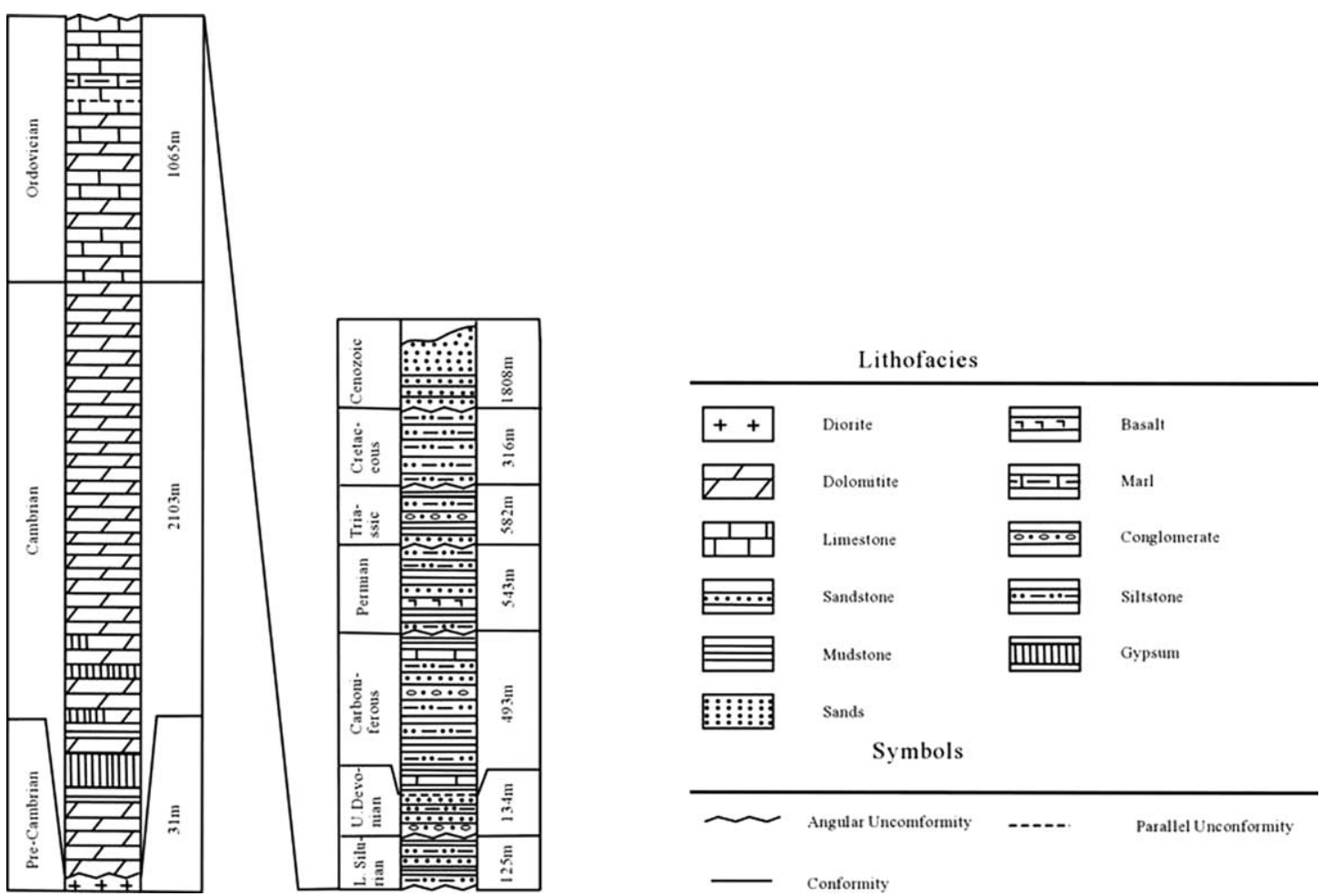

Fig. 3. Stratigraphic section penetrated by TC-1 well in central Tarim. The basement samples (G-1, G-2, and G-3) analyzed for this study were collected from drill cores below Cambrian-basement unconformity at stratigraphic intervals between 7165 and 7168 . See text for details. 
(Fig. 2). The folded Paleozoic strata form a structural high, known as the central Tarim uplift trending east and extending across the entire basin (Fig. 1). The Carboniferous unconformity marks the end of a major orogenic event not only recorded in the Tarim basin but extensively in the northern Tibetan plateau. This event may possibly be related to complex collisional tectonics between one or several island arcs and the North China and Tarim continental blocks (Yin and Nie, 1996; Sobel and Arnaud, 1999; Yin and Harrison, 2000; Gehrels et al., 2003a,b). The evidence for several major Phanerozoic deformational events in the Tarim basin indicates that this area was quite deformable prior to the Indo-Asian collision, as discussed by Jia (1997).

In order to constrain the composition of the Tarim basement, a deep well-the Tarim Geological Survey Well (TC-1)—was drilled across the central Tarim uplift (Zhou et al., 2002) (Fig. 2). A complete stratigraphic section penetrated by the Tarim Geological Survey Well is shown in Fig. 3. Regional angular unconformities as imaged by reflection seismic profiles and drill core data are also shown in Fig. 3. Above the Ordovician and Silurian unconformity is a sequence of sandstone, siltstone, and conglomerate with a minor amount of limestone. Below this unconformity is a thick sequence of Cambrian-Ordovician shallow-marine carbonate locally interbedded with gypsum at its base. The Ordovician sequence is a $\sim 2 \mathrm{~km}$ thick carbonate succession. A parallel unconformity is present in the upper part of the Ordovician carbonate. In the deepest section, the well drilled into an undeformed pluton for about $38 \mathrm{~m}$ below the unconformity at the base of the Cambrian strata (Fig. 3).

\section{Geochemistry and geochronology}

Three pieces of rock fragments, with sizes ranging from 2 to $4 \mathrm{~cm}$ in the longest dimension were recovered from drill cores of the Tarim Geological Survey Well (TC-1) at the stratigraphic intervals between 7165 and $7168 \mathrm{~m}$ (Fig. 3). Information on the exact depth of each rock fragment is not available. Observations of thin sections show that the samples are overall quite fresh and the igneous textures are well preserved (Fig. 4a). Two rock types can be recognized from the samples: fine-grained and medium-grained (Fig. 4b and c). The transition between the fine-grained and mediumgrained domains is sharp and the change in grain size is extremely abrupt, as well preserved in sample G-3 in which fine-grained domains form inclusions (Fig. 4c). The medium-grained domain consists of $60-65 \%$ plagioclase (mostly andesines), 30-35\% hornblende, $<3 \% \mathrm{Ti}-\mathrm{Fe}$ oxide, and $<1 \%$ apatite. Similar mineralogical compositions are also observed for the fine-grained domain. In general, the fine-grained domains in all samples occur as small patches included in the medium-grained domains. It is possible that the two textural domains represent two phases of igneous intrusion.
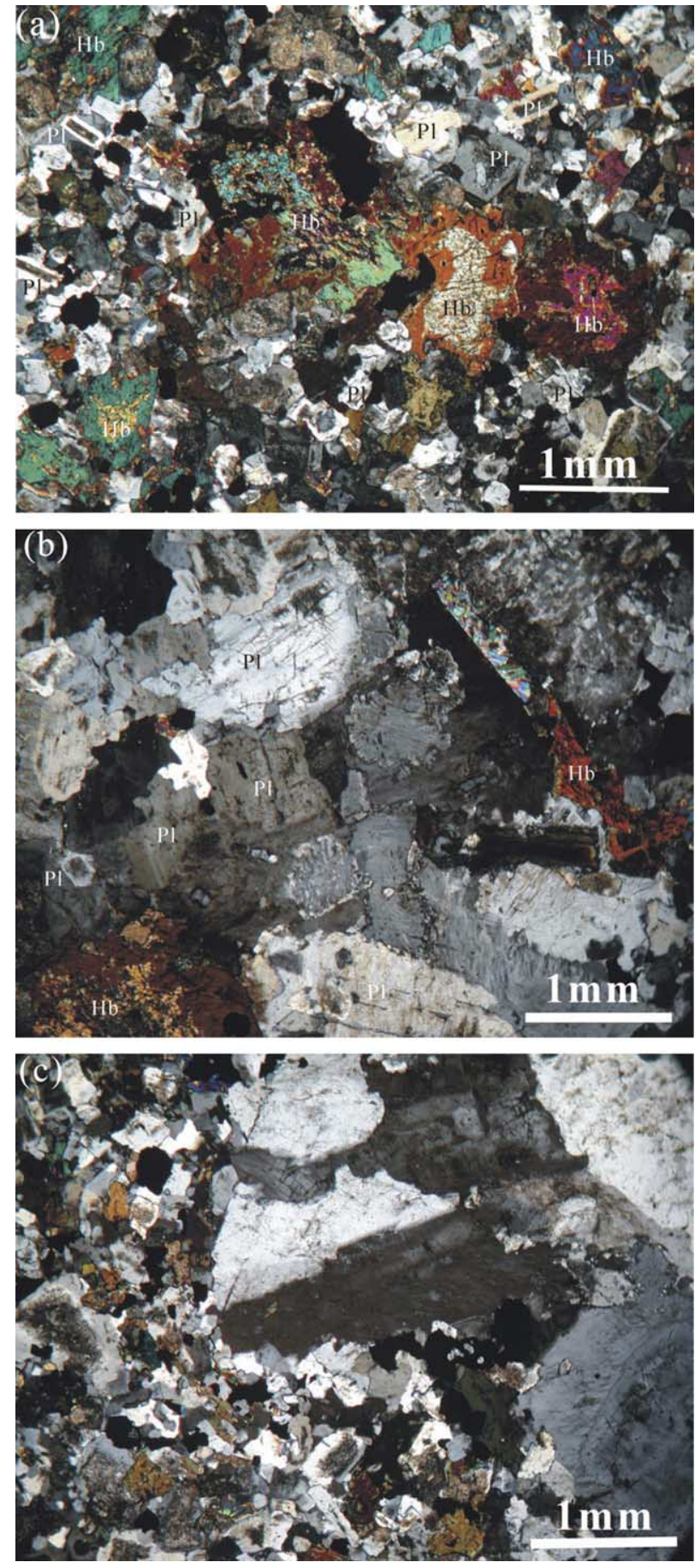

Fig. 4. Photographs of mineral composition and textural relationships of samples G-1, G-2, and G-3 from TC-1 well. (a) Fine-grained diorite for sample G-1. (b) Medium-grained diorite for sample G-3. (c) The abrupt contact between fine-grained and medium-grained domains for sample G-2. $\mathrm{Pl}$, plagioclase; $\mathrm{Hb}$, hornblende.

Analysis of major elements shows that the composition of the samples falls in the field of diorite (with $\mathrm{SiO}_{2}$ ranging from 54.7 to $55.2 \mathrm{wt} \%$ ) (Table 1). The $\mathrm{Na}_{2} \mathrm{O}$ content $(5.63-5.76 \mathrm{wt} \%)$ is higher than that of $\mathrm{K}_{2} \mathrm{O}$ (2.39-2.67 wt \%) when compared to typical calc-alkaline rocks (Defant and Drmmont, 1990). Although, REE 
Table 1

Compositions of major oxides for samples G-1, G-2, and G-3

\begin{tabular}{|c|c|c|c|c|c|c|c|c|c|c|c|c|c|}
\hline Samples & $\mathrm{SiO}_{2}$ & $\mathrm{TiO}_{2}$ & $\mathrm{Al}_{2} \mathrm{O}_{3}$ & $\mathrm{FeO}$ & $\mathrm{Fe}_{2} \mathrm{O}_{3}$ & $\mathrm{MnO}$ & $\mathrm{CaO}$ & $\mathrm{MgO}$ & $\mathrm{K}_{2} \mathrm{O}$ & $\mathrm{Na}_{2} \mathrm{O}$ & $\mathrm{P}_{2} \mathrm{O}_{5}$ & LOI & Total \\
\hline G-1 & 54.7 & 1.13 & 17.04 & 2.42 & 1.96 & 0.56 & 7.35 & 3.52 & 2.39 & 5.63 & 0.89 & 1.81 & 99.4 \\
\hline G-3 & 55.2 & 0.67 & 18.52 & 2.16 & 3.57 & 0.44 & 6.13 & 2.31 & 2.67 & 5.76 & 0.57 & 1.67 & 99.68 \\
\hline
\end{tabular}

(rare earth elements) contents are variable (Table 2), the chondrite-normalized REE patterns are similar with moderately enriched light REE (Fig. 5). There are no significant Eu anomalies. The trace element patterns normalized by the primitive mantle (Sun and McDonough, 1989) show generally similar shapes (Fig. 5a) and display strong depletion in $\mathrm{Nb}$ and $\mathrm{Ta}$, which is typical for subductionrelated igneous rocks (e.g. Briqueu et al., 1984). The samples fall within the volcanic-arc granitoid field in $\mathrm{Rb}$ versus $\mathrm{Y}+\mathrm{Nb}$ and $\mathrm{Rb}$ versus $\mathrm{Yb}+\mathrm{Ta}$ discrimination diagrams (Fig. 5b and c) (Pearce et al., 1984). The initial $\varepsilon_{\mathrm{Nd}}$ values are between -4.4 and -9.5 and the initial ${ }^{87} \mathrm{Sr} /{ }^{86} \mathrm{Sr}$ values are between 0.705756 and 0.706666 (Table 3), which are characteristic of granitoids in a volcanic arc setting (e.g. Barbarin, 1999).

In order to constrain the age of the pluton, we performed thermochronologic analysis of mineral separates from the samples. Although, our original intention was to determine the crystallization age of the granitoid using $\mathrm{U}-\mathrm{Pb}$ zircon geochronology, we were unable to recover zircon grains from the samples. However, constraints on the age of the pluton were obtained from ${ }^{40} \mathrm{Ar} /{ }^{39} \mathrm{Ar}$ analyses of hornblende. Analyses were performed at UCLA. Detailed analytical procedures can be found in McDougall and Harrison (1999). Mineral separates and sanidine flux monitors were irradiated at the Ford reactor, University of Michigan, for 45 hours. Reactor neutron flux was determined using sanidine standard Fish Canyon Tuff (27.8 Ma) (Cebula et al., 1986; Renne et al., 1994). After irradiation, samples were step heated in a Ta crucible in a double vacuum furnace and isotopic compositions of the released gas determined using a gas-source automated mass-spectrometer. Isotopic data were reduced using an in-house data reduction program, AGECAL.EXE. Age uncertainties are reported at the $1 \sigma$ level, and do not include uncertainties in J-Factors or decay constants.

The results of ${ }^{40} \mathrm{Ar} /{ }^{39} \mathrm{Ar}$ analyses of hornblendes are summarized in Tables 4-6 and Fig. 6. Samples G-1, G-2, and G-3 yielded weighted mean plateau ages of $790.0 \pm 22.1,754.4 \pm 22.6$, and 744.0 $\pm 9.3 \mathrm{Ma}$, respectively. Although, the samples were collected over a distance $<35 \mathrm{~m}$ (the total drill distance into the basement), the cooling ages vary considerably, from $\sim 744$ to $790 \mathrm{Ma}$. The oldest and youngest ages are distinctively different even considering the relatively large uncertainties of each analysis (reported at $1 \sigma$ ). One explanation for the variation of hornblende ages is that it reflects partial diffusion loss of ${ }^{40} \mathrm{Ar}$ due to long residence at temperatures close to or slightly higher than the hornblende closure temperature. In this case, the oldest hornblende age would provide a minimum age of the pluton emplacement, and suggests emplacement at mid-crustal depths $(>16 \mathrm{~km}$ assuming a $30{ }^{\circ} \mathrm{C} / \mathrm{km}$ geotherm and $500{ }^{\circ} \mathrm{C}$ closure temperature for hornblende). Alternatively, the contrastingly different ages may represent two phases of pluton emplacement. This interpretation seems unlikely because the potential two phases of intrusive activities as represented by different textural domains are seperated by few $\mathrm{mm}$. Additionally, all samples were collected from within a distance of $<35 \mathrm{~m}$ so that any later intrusion would have thermally reset the older hornblende ages. In either case, plutonism in the central Tarim region must have initiated before $790 \mathrm{Ma}$, and may have lasted for an extended period (i.e. after $740 \mathrm{Ma}$ ).

Table 2

Trace elemental abundance of central Tarim granitoid

\begin{tabular}{|c|c|c|c|}
\hline Samples & G-1 & G-2 & G-3 \\
\hline $\mathrm{Cr}$ & 67,276 & 254,181 & 16,295 \\
\hline $\mathrm{Co}$ & 10,933 & 3948.4 & 6274.1 \\
\hline $\mathrm{Ni}$ & 27,360 & 98,896 & 333.4 \\
\hline $\mathrm{Cu}$ & 23,265 & 23,220 & 22,185 \\
\hline $\mathrm{Zn}$ & 179,862 & 180,145 & 130,495 \\
\hline $\mathrm{Rb}$ & 53,474 & 110,323 & 51,860 \\
\hline $\mathrm{Sr}$ & $1,645,710$ & $1,829,370$ & $1,757,560$ \\
\hline $\mathrm{Y}$ & 44,765 & 38,925 & 24,582 \\
\hline $\mathrm{Zr}$ & 90,654 & 289,596 & 46,631 \\
\hline $\mathrm{Nb}$ & 8876.8 & 11,933 & 4696.7 \\
\hline $\mathrm{Sn}$ & 2397 & 1864.6 & 2001.3 \\
\hline $\mathrm{Cs}$ & 1126.2 & 1040.3 & 1353 \\
\hline $\mathrm{Ba}$ & 944,378 & $2,710,490$ & $1,071,260$ \\
\hline $\mathrm{La}$ & 94,912 & 67,253 & 58,936 \\
\hline $\mathrm{Ce}$ & 198,567 & 148,711 & 116,127 \\
\hline $\operatorname{Pr}$ & 23,532 & 18,778 & 13,524 \\
\hline $\mathrm{Nd}$ & 103,663 & 82,361 & 57,800 \\
\hline $\mathrm{Sm}$ & 17,614 & 14,405 & 9774 \\
\hline En & 3225.2 & 3682.1 & 2083.8 \\
\hline $\mathrm{Gd}$ & 14,038 & 11,857 & 7836.9 \\
\hline $\mathrm{Tb}$ & 1944.3 & 1548.3 & 1080.7 \\
\hline Dy & 9320.5 & 8015.8 & 5141.5 \\
\hline Ho & 1775.9 & 1534.7 & 964.65 \\
\hline $\mathrm{Er}$ & 4880.4 & 4210.7 & 2641 \\
\hline $\mathrm{Tm}$ & 616.13 & 579.97 & 349.64 \\
\hline $\mathrm{Yb}$ & 3867.5 & 3688.5 & 2048.8 \\
\hline $\mathrm{Lu}$ & 587.12 & 559.04 & 328.11 \\
\hline Hf & 2992.6 & 6904.9 & 1388.5 \\
\hline $\mathrm{Ta}$ & 332.82 & 832.84 & 147.91 \\
\hline $\mathrm{Pb}$ & 12,557 & 22,462 & 10813 \\
\hline $\mathrm{Bi}$ & 80.283 & 6.9026 & \\
\hline Th & 6338.3 & 9369.1 & 3552.5 \\
\hline $\mathrm{U}$ & 1020.5 & 1714.3 & 646.68 \\
\hline
\end{tabular}



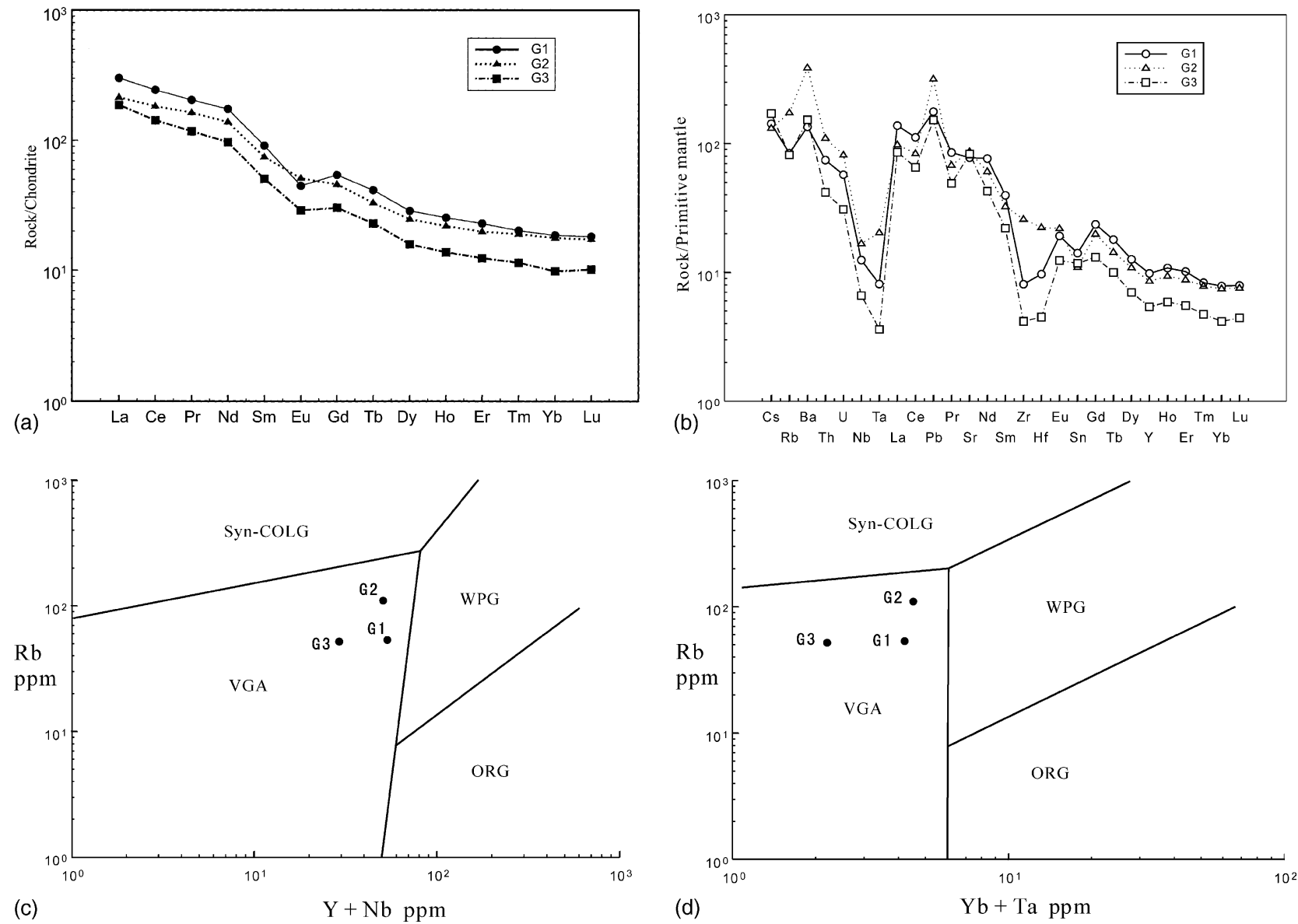

Fig. 5. (a) Chondrite-normalized REE patterns for samples from TC-1 well. (b) Primitive mantle-normalized trace element patterns for rocks from drill hole of central Tarim. (c) Rb versus $\mathrm{Y}+\mathrm{Nb}$ and (d) Rb versus $\mathrm{Yb}+\mathrm{Ta}$ discriminant diagrams. Tectonic classification follows that of Pearce et al. (1984): Syn-COLG, syn-collision granite; VAG, arc granite; WPG, within-plate granite; ORG, mid-ocean-ridge granite.

Our age constraints for the central Tarim pluton are consistent with the geologic constraint that the intrusion is older than Cambrian as the pluton lies unconformably below Cambrian strata (Fig. 3).

\section{Discussion}

\subsection{Precambrian geology}

The above results suggest that the basement of the central Tarim basin is composed of a Precambrian undeformed pluton. Observations from thin sections and major element analysis suggest that the pluton is a diorite of intermediate composition. The trace element patterns and initial $\varepsilon_{\mathrm{Nd}}$ and ${ }^{87} \mathrm{Sr} /{ }^{86} \mathrm{Sr}$ values all suggest the pluton was derived from an arc setting. These new results do not favor the hypotheses that the Tarim basement (at least in its central part) is composed by late Paleozoic remnant oceanic crust or Proterozoic oceanic plateau. Instead, they suggest that a Precambrian arc might be present across the central Tarim basin and may extend to the Tian Shan to the north and the Altyn Tagh range to the south as discussed below.
The possible existence of a magamtic arc beneath the central Tarim basin raises the question how it extends spatially across the basin and correlates with geology in the Tian Shan and Tibet. Geologic evidence for a Proterozoic

Table 3

$\mathrm{Sr}$ and $\mathrm{Nd}$ isotopic values of central Tarim granitoid

\begin{tabular}{llll}
\hline Samples & G-1 & G-2 & G-3 \\
\hline $\mathrm{Sm}(\mathrm{ppm})$ & 16.18 & 13.58 & 9.903 \\
$\mathrm{Nd}(\mathrm{ppm})$ & 62.31 & 75.55 & 56.02 \\
${ }^{147} \mathrm{Sm} /{ }^{144} \mathrm{Nd}$ & 0.15700 & 0.10870 & 0.10690 \\
${ }^{143} \mathrm{Nd} /{ }^{144} \mathrm{Nd}$ & $0.511956 \pm 11$ & $0.511962 \pm 8$ & $0.511933 \pm 10$ \\
$\varepsilon_{\mathrm{Nd}}(0)$ & -13.3 & -13.2 & -13.8 \\
$\varepsilon_{\mathrm{Nd}}(\mathrm{T})$ & -9.5 & -4.4 & -4.8 \\
$\mathrm{Rb}(\mathrm{ppm})$ & 53.24 & 113.29 & 64.89 \\
$\mathrm{Sr}(\mathrm{ppm})$ & 1675.03 & 1813.07 & 2002.17 \\
${ }^{87} \mathrm{Rb} /{ }^{86} \mathrm{Sr}$ & 0.092 & 0.181 & 0.094 \\
$\left({ }^{87} \mathrm{Sr} /{ }^{86} \mathrm{Sr}\right)_{\mathrm{I}}$ & 0.705756 & 0.706666 & 0.705994 \\
$2 \sigma$ & 0.000018 & 0.000018 & 0.000015 \\
\hline
\end{tabular}

(1) All measured ${ }^{143} \mathrm{Nd} /{ }^{144} \mathrm{Nd}$ ratios are normalized to ${ }^{146} \mathrm{Nd} /{ }^{144} \mathrm{Nd}=0.7219$, further adjusted to ${ }^{143} \mathrm{Nd} /{ }^{144} \mathrm{Nd}=0.511859$ for the La Jolla, the lab blank background of Sm-Nd is about $5 \times 10^{-11} \mathrm{~g}$. (2) All measured ${ }^{87} \mathrm{Sr} /{ }^{86} \mathrm{Sr}$ ratios are normalized to ${ }^{86} \mathrm{Sr} /{ }^{88} \mathrm{Sr}=0.1194$. The lab blank background of $\mathrm{Rb}-\mathrm{Sr}$ is about $2-5 \times 10^{-10} \mathrm{~g}$. 
Table 4

Analytical data of ${ }^{40} \mathrm{Ar} /{ }^{39} \mathrm{Ar}$ thermochronologic analysis of hornblende for sample G-1

\begin{tabular}{|c|c|c|c|c|c|c|c|c|c|c|c|c|c|}
\hline Step & $T(\mathrm{C})$ & $T(\min )$ & ${ }^{40} \mathrm{Ar} /{ }^{39} \mathrm{Ar}^{\mathrm{a}}$ & ${ }^{38} \mathrm{Ar}^{39} \mathrm{Ar}^{\mathrm{a}}$ & ${ }^{37} \mathrm{Ar} /{ }^{39} \mathrm{Ar}{ }^{a}$ & ${ }^{36} \mathrm{Ar} /{ }^{39} \mathrm{Ar}^{\mathrm{a}}$ & ${ }^{39} \mathrm{Ar}_{\mathrm{K}}(\mathrm{mol})^{\mathrm{b}}$ & $\Sigma^{39} \mathrm{Ar}_{\mathrm{K}}$ & $\%^{40} \mathrm{Ar}^{* \mathrm{c}}$ & ${ }^{40} \mathrm{Ar}^{*} \beta^{39} \mathrm{Ar}_{\mathrm{K}}^{\mathrm{d}}$ & $\pm \sigma_{40 / 39}$ & $\operatorname{Age}(\mathrm{Ma})^{\mathrm{e}}$ & $\pm \sigma_{\mathrm{Age}}(\mathrm{an})$ \\
\hline 1 & 700 & 10 & 144.689 & 1.560 & 3.616 & $1.376 \times 10^{-1}$ & $4.340 \times 10^{-15}$ & 4.1 & 72.1 & 104.647 & 0.573 & 1019.07 & 4.26 \\
\hline 2 & 800 & 10 & 69.855 & $3.222 \times 10^{-1}$ & 2.338 & $3.250 \times 10^{-2}$ & $3.260 \times 10^{-15}$ & 7.2 & 86.3 & 60.541 & 0.266 & 656.87 & 2.42 \\
\hline 3 & 900 & 10 & 63.394 & $1.685 \times 10^{-1}$ & 1.699 & $1.360 \times 10^{-2}$ & $3.650 \times 10^{-15}$ & 10.6 & 93.7 & 59.576 & 0.216 & 648.08 & 1.98 \\
\hline 4 & 10000 & 10 & 73.045 & $3.412 \times 10^{-1}$ & 4.271 & $1.100 \times 10^{-2}$ & $6.850 \times 10^{-15}$ & 17.1 & 95.9 & 70.388 & 0.501 & 744.27 & 4.34 \\
\hline 5 & 1050 & 10 & 71.080 & $4.457 \times 10^{-1}$ & 6.340 & $5.170 \times 10^{-2}$ & $2.040 \times 10^{-14}$ & 36.4 & 98.5 & 70.458 & 0.197 & 744.88 & 1.70 \\
\hline 6 & 1100 & 13 & 71.527 & $4.484 \times 10^{-1}$ & 6.275 & $4.210 \times 10^{-2}$ & $3.270 \times 10^{-14}$ & 67.3 & 98.9 & 71.184 & 0.117 & 751.15 & 1.01 \\
\hline 7 & 1150 & 10 & 79.481 & $4.712 \times 10^{-1}$ & 8.635 & $7.600 \times 10^{-2}$ & $1.510 \times 10^{-14}$ & 81.6 & 98.0 & 78.537 & 0.234 & 813.53 & 1.95 \\
\hline 8 & 1200 & 10 & 84.039 & $5.892 \times 10^{-1}$ & $1.627 \times 10^{1}$ & $1.160 \times 10^{-2}$ & $8.830 \times 10^{-15}$ & 90.0 & 97.4 & 83.147 & 0.356 & 851.56 & 2.91 \\
\hline 9 & 1350 & 10 & 77.687 & $7.799 \times 10^{-1}$ & $5.247 \times 10^{1}$ & $2.210 \times 10^{-2}$ & $9.710 \times 10^{-15}$ & 99.1 & 97.3 & 79.212 & 0.361 & 819.15 & 3.00 \\
\hline
\end{tabular}

Corrected for nucleogenic interferences.

${ }^{a}$ Corrected for backgrounds, mass discrimination, abundance sensitivity, and radioactive decay using the following: Backgrounds: $\mathrm{m} / \mathrm{e} 40(\mathrm{~mol}), 2.6 \times 10^{-16} ; \mathrm{m} / \mathrm{e} 39(\mathrm{~mol}), 5.9 \times 10^{-17}$; m/e 38 (mol), $1.8 \times 10^{-17} ; \mathrm{m} / \mathrm{e} 37(\mathrm{~mol}), 2.2 \times 10^{-17} ; \mathrm{m} / \mathrm{e} 36(\mathrm{~mol}), 1.3 \times 10^{-17} ;$ Measured ${ }^{40} \mathrm{Ar}^{36} \mathrm{Ar}_{\mathrm{ATM}}: 294.7 \pm 0.5$; abundance sensitivity: 5 ppm.

${ }^{\mathrm{b}}$ Normalized to $100 \%$ delivery to mass spectrometer.

${ }^{c}$ Includes contribution from static line blank.

${ }^{\mathrm{d}}$ Corrected for atmospheric argon and nucleogenic interferences using the following: ${ }^{40} \mathrm{Ar} /{ }^{39} \mathrm{Ar}_{\mathrm{k}}, 0.0234 ;{ }^{36} \mathrm{Ar} /{ }^{37} \mathrm{Arc} \mathrm{c}_{\mathrm{a}}, 0.000292 ;{ }^{39} \mathrm{Ar} /{ }^{37} \mathrm{Arc} \mathrm{c}_{\mathrm{a}}, 0.000854$

${ }^{\mathrm{e}}$ Assumes trapped argon is atmospheric. J-factor: 0.007255 (assumes Fish Canyon sanidine, 27.8 Ma).

Table 5

Analytical data of ${ }^{40} \mathrm{Ar} /{ }^{39} \mathrm{Ar}$ thermochronologic analysis of hornblende for sample $\mathrm{G}-2$

\begin{tabular}{|c|c|c|c|c|c|c|c|c|c|c|c|c|c|}
\hline Step & $T(\mathrm{C})$ & $T(\min )$ & ${ }^{40} \mathrm{Ar} /{ }^{39} \mathrm{Ar}^{\mathrm{a}}$ & ${ }^{38} \mathrm{Ar} /{ }^{39} \mathrm{Ar}^{\mathrm{a}}$ & ${ }^{37} \mathrm{Ar} /{ }^{39} \mathrm{Ar}^{\mathrm{a}}$ & ${ }^{36} \mathrm{Ar} /{ }^{39} \mathrm{Ar}^{\mathrm{a}}$ & ${ }^{39} \mathrm{Ar}_{\mathrm{K}}(\mathrm{mol})^{\mathrm{b}}$ & $\Sigma^{39} \mathrm{Ar}_{\mathrm{K}}$ & $\%^{40} \mathrm{Ar}^{* \mathrm{c}}$ & ${ }^{40} \mathrm{Ar}^{*} \beta^{39} \mathrm{Ar}_{\mathrm{K}}^{\mathrm{d}}$ & $\pm \sigma_{40 / 39}$ & $\operatorname{Age}(\mathrm{Ma})^{\mathrm{e}}$ & $\pm \sigma_{\mathrm{Age}}(\mathrm{an})$ \\
\hline 1 & 700 & 10 & 225.195 & 1.884 & 3.739 & $2.901 \times 10^{-1}$ & $3.200 \times 10^{-15}$ & 4.4 & 62.0 & 104.212 & 3.378 & 1266.72 & 21.93 \\
\hline 2 & 800 & 10 & 96.810 & $5.079 \times 10^{-1}$ & 4.538 & $6.090 \times 10^{-2}$ & $2.070 \times 10^{-15}$ & 7.2 & 81.6 & 79.485 & 0.585 & 821.96 & 4.86 \\
\hline 3 & 900 & 10 & 101.246 & $4.494 \times 10^{-1}$ & 4.168 & $5.320 \times 10^{-2}$ & $1.880 \times 10^{-15}$ & 9.8 & 84.6 & 86.170 & 0.448 & 876.65 & 3.61 \\
\hline 4 & 10000 & 10 & 90.088 & $3.851 \times 10^{-1}$ & 8.278 & $3.160 \times 10^{-2}$ & $3.680 \times 10^{-15}$ & 14.8 & 90.3 & 82.033 & 0.141 & 843.00 & 1.16 \\
\hline 5 & 1050 & 10 & 73.632 & $3.729 \times 10^{-1}$ & 7.532 & $1.271 \times 10^{-2}$ & $8.940 \times 10^{-15}$ & 27.1 & 95.7 & 70.959 & 0.230 & 749.72 & 1.99 \\
\hline 6 & 1100 & 10 & 72.068 & $3.860 \times 10^{-1}$ & 7.409 & $5.860 \times 10^{-3}$ & $2.390 \times 10^{-14}$ & 59.9 & 98.4 & 71.404 & 0.086 & 753.56 & 0.74 \\
\hline 7 & 1150 & 10 & 71.029 & $3.140 \times 10^{-1}$ & 7.933 & $8.960 \times 10^{-3}$ & $9.830 \times 10^{-15}$ & 73.3 & 97.1 & 69.513 & 0.103 & 737.17 & 0.90 \\
\hline 8 & 1200 & 10 & 75.950 & $3.648 \times 10^{-1}$ & $1.499 \times 10^{1}$ & $1.420 \times 10^{-2}$ & $7.150 \times 10^{-15}$ & 83.2 & 96.1 & 73.962 & 0.240 & 775.50 & 2.04 \\
\hline 9 & 1350 & 10 & 92.340 & $6.512 \times 10^{-1}$ & $6.412 \times 10^{1}$ & $3.610 \times 10^{-2}$ & $1.230 \times 10^{-15}$ & 100.0 & 94.3 & 92.231 & 0.150 & 924.84 & 1.18 \\
\hline 10 & 1500 & 10 & 1058.380 & 1.184 & $2.142 \times 10^{2}$ & 3.197 & $1.160 \times 10^{-17}$ & 100.0 & 12.0 & 161.529 & 635.065 & 1400.05 & 3828.58 \\
\hline
\end{tabular}

Corrected for nucleogenic interferences.
Corrected for backgrounds, mass discrimination, abundance sensitivity, and radioactive decay using the following: Backgrounds: $\mathrm{m} / \mathrm{e} 40$ (mol), $2.6 \times 10^{-16} ; \mathrm{m} / \mathrm{e} 39$ (mol), $5.9 \times 10^{-17} ; \mathrm{m} / \mathrm{e} 38$ (mol), $.9 \times 10^{-17} ; \mathrm{m} / \mathrm{e} 37(\mathrm{~mol}), 2.3 \times 10^{-17} ; \mathrm{m} / \mathrm{e} 36(\mathrm{~mol}), 1.3 \times 10^{-17} ;$ Measured ${ }^{40} \mathrm{Ar}^{36} \mathrm{Ar}_{\mathrm{ATM}}, 294.7 \pm 0.5 ;$ abundance sensitivity: $5 \mathrm{ppm}$.

b Normalized to $100 \%$ delivery to mass spectrometer.

${ }^{\mathrm{c}}$ Includes contribution from static line blank.

${ }^{\mathrm{d}}$ Corrected for atmospheric argon and nucleogenic interferences using the following: ${ }^{40} \mathrm{Ar}^{39}{ }^{39} \mathrm{Ar}_{\mathrm{k}}: 0.0234,{ }^{36} \mathrm{Ar} /{ }^{37} \mathrm{Arc}_{\mathrm{a}}: 0.000292,{ }^{39} \mathrm{Ar}^{37} \mathrm{Arc}_{\mathrm{a}}: 0.000854$.

e Assumes trapped argon is atmospheric. J-factor: 0.007261 (assumes Fish Canyon sanidine, 27.8 Ma). 
Analytical data of ${ }^{40} \mathrm{Ar} /{ }^{39} \mathrm{Ar}$ thermochronologic analysis of hornblende for sample G-3

\begin{tabular}{|c|c|c|c|c|c|c|c|c|c|c|c|c|c|}
\hline Step & $T(\mathrm{C})$ & $T(\min )$ & ${ }^{40} \mathrm{Ar}^{39} \mathrm{Ar}^{\mathrm{a}}$ & ${ }^{38} \mathrm{Ar} /{ }^{39} \mathrm{Ar}^{\mathrm{a}}$ & ${ }^{37} \mathrm{Ar} /{ }^{39} \mathrm{Ar}^{\mathrm{a}}$ & ${ }^{36} \mathrm{Ar} /{ }^{39} \mathrm{Ar}^{\mathrm{a}}$ & ${ }^{39} \mathrm{Ar}_{\mathrm{K}}(\mathrm{mol})^{\mathrm{b}}$ & $\Sigma^{39} \mathrm{Ar}_{\mathrm{K}}$ & $\%^{40} \mathrm{Ar}^{* \mathrm{c}}$ & ${ }^{40} \mathrm{Ar}^{*} \beta^{39} \mathrm{Ar}_{\mathrm{K}}^{\mathrm{d}}$ & $\pm \sigma_{10 / 39}$ & $\operatorname{Age}(\mathrm{Ma})^{\mathrm{e}}$ & $\pm \sigma_{\mathrm{Age}}(\mathrm{an})$ \\
\hline 1 & 700 & 10 & 99.329 & $9.058 \times 10^{-1}$ & 2.448 & $9.660 \times 10^{-2}$ & $5.080 \times 10^{-15}$ & 4.9 & 71.4 & 71.125 & 0.329 & 749.21 & 2.84 \\
\hline 2 & 800 & 10 & 63.695 & $1.202 \times 10^{-1}$ & 1.527 & $1.830 \times 10^{-2}$ & $4.380 \times 10^{-15}$ & 9.1 & 91.5 & 58.465 & 0.168 & 636.64 & 1.54 \\
\hline 3 & 900 & 10 & 65.674 & $9.870 \times 10^{-2}$ & 1.329 & $9.680 \times 10^{-3}$ & $4.860 \times 10^{-15}$ & 13.8 & 95.7 & 62.977 & 0.327 & 677.57 & 2.93 \\
\hline 4 & 10000 & 10 & 71.800 & $2.410 \times 10^{-1}$ & 3.520 & $9.070 \times 10^{-3}$ & $8.110 \times 10^{-15}$ & 21.6 & 96.6 & 69.608 & 0.133 & 736.09 & 1.16 \\
\hline 5 & 1050 & 10 & 72.524 & $4.112 \times 10^{-1}$ & 5.952 & $4.290 \times 10^{-3}$ & $1.050 \times 10^{-14}$ & 31.7 & 98.7 & 72.113 & 0.255 & 757.70 & 2.19 \\
\hline 6 & 1100 & 10 & 71.162 & $4.046 \times 10^{-1}$ & 5.556 & $3.340 \times 10^{-3}$ & $3.490 \times 10^{-14}$ & 65.3 & 99.2 & 70.969 & 0.052 & 747.86 & 0.45 \\
\hline 7 & 1150 & 10 & 72.828 & $4.273 \times 10^{-1}$ & 7.109 & $4.290 \times 10^{-3}$ & $1.040 \times 10^{-14}$ & 75.3 & 98.9 & 72.590 & 0.186 & 761.79 & 1.59 \\
\hline 8 & 1200 & 10 & 76.242 & $4.893 \times 10^{-1}$ & 8.658 & $7.170 \times 10^{-3}$ & $1.130 \times 10^{-14}$ & 86.1 & 98.1 & 75.404 & 0.335 & 785.72 & 2.83 \\
\hline 9 & 1250 & 10 & 75.174 & $5.019 \times 10^{-1}$ & $1.426 \times 10^{1}$ & $9.600 \times 10^{-3}$ & $9.830 \times 10^{-15}$ & 95.6 & 97.7 & 74.451 & 0.166 & 777.66 & 1.40 \\
\hline 10 & 1350 & 10 & 78.162 & $5.376 \times 10^{-1}$ & $2.352 \times 10^{1}$ & $2.190 \times 10^{-2}$ & $3.200 \times 10^{-15}$ & 98.7 & 94,1 & 75.202 & 0.317 & 784.01 & 2.68 \\
\hline 11 & 1500 & 10 & 97.424 & $5.456 \times 10^{-1}$ & $2.105 \times 10^{1}$ & $8.700 \times 10^{-2}$ & $1.390 \times 10^{-15}$ & 100.0 & 75.2 & 74.859 & 0.700 & 781.11 & 5.93 \\
\hline
\end{tabular}

Corrected for backgrounds, mass discrimination, abundance sensitivity, and radioactive decay using the following: Backgrounds: $\mathrm{m} / \mathrm{e} 40(\mathrm{~mol}), 2.8 \times 10^{-16} ; \mathrm{m} / \mathrm{e} 39(\mathrm{~mol}), 5.9 \times 10^{-17} ; \mathrm{m} / \mathrm{e} 38$ (mol), $1.9 \times 10^{-17} ; \mathrm{m} / \mathrm{e} 37(\mathrm{~mol}), 2.3 \times 10^{-17} ; \mathrm{m} / \mathrm{e} 36(\mathrm{~mol}), 1.4 \times 10^{-17} ;$ Measured ${ }^{40} \mathrm{Ar}^{36} \mathrm{Ar}_{\mathrm{ATM}}, 294.7 \pm 0.5$; abundance sensitivity: $5 \mathrm{ppm}$.

bormalized to $100 \%$ delivery to mass spectrometer.

${ }^{\mathrm{c}}$ Includes contribution from static line blank.

${ }^{\mathrm{d}}$ Corrected for atmospheric argon and nucleogenic interferences using the following: ${ }^{40} \mathrm{Ar} /{ }^{39} \mathrm{Ar}_{\mathrm{k}}, 0.0234 ;{ }^{36} \mathrm{Ar} /{ }^{37} \mathrm{Arc} \mathrm{c}_{\mathrm{a}}, 0.000292 ;{ }^{39} \mathrm{Ar} /{ }^{37} \mathrm{Arc} \mathrm{c}_{\mathrm{a}}, 0.000854$.

e Assumes trapped argon is atmospheric. J-factor: 0.007238 (assumes Fish Canyon sanidine, 27.8 Ma).
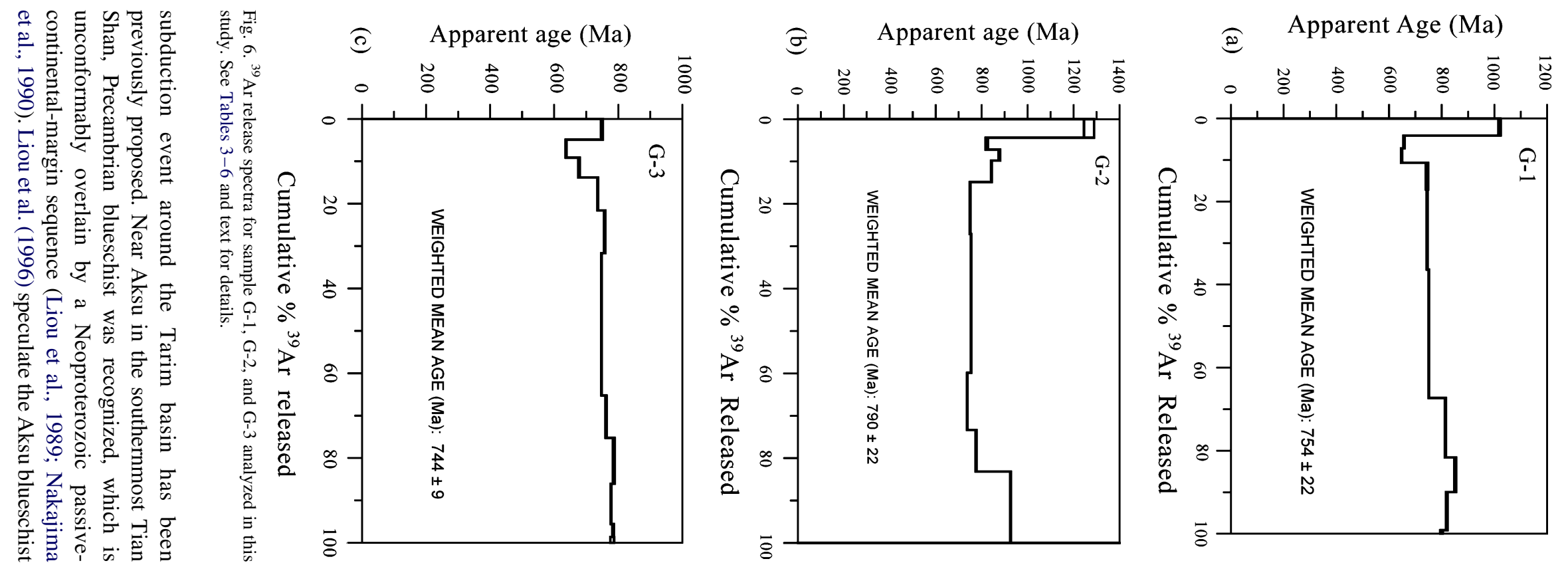
to represent a remnant suture between the Tarim block in the south and the Kazakstan-Yili microcontinent to the north. This tectonic division is quite different from that of Gao et al. (1998) and Gao and Klemd (2003) who used an early Paleozoic blueschist belt in the central Tian Shan as the suture between the Tarim and Kazakstan-Yili blocks which was closed in the Carboniferous (Gao et al., 1998). The limited exposure of the Precambrian blueschist belt in the southern Tian Shan and complication from Cenozoic crustal shortening (Yin et al., 1998; Allen et al., 1999; Burchfiel et al., 1999) make it difficult to determine directly its relationship to the Paleozoic blueschist belt in the central Tian Shan to the north. Because their age differences, we conclude that the two blueschist belts may represent different tectonic events. We speculate that the development of the Precambrian blueschist belt of Liou et al. (1989) may have been associated with the central Tarim arc as part of the same subduction system.

Late Proterozoic granitoids are also found in the central Altyn Tagh range immediately south of the Tarim basin, where a deformed granitoid was dated by the $\mathrm{U}-\mathrm{Pb}$ method at $969 \pm 6 \mathrm{Ma}$ by Cowgill et al. (2003). About $100 \mathrm{~km}$ to the east in the eastern Altyn Tagh range north of the Altyn Tagh fault, a granitoid was dated to be $922 \pm 6 \mathrm{Ma}$ by the $\mathrm{U}-\mathrm{Pb}$ method (Gehrels et al., 2003a). A Late Proterozoic granitoid intruding a passive continental margin sequence was also dated as $922 \pm 5 \mathrm{Ma}$ in the northern Qilian Shan south of the Altyn Tagh fault (Gehrels et al., 2003a). The mineral composition and geochemical signatures of the granitoids in the Altyn Tagh range and the Qilian Shan have not been studied, and thus their tectonic origin is unknown. However, these plutons in northern Tibet could be the eastern extension of the Precambrian magmatic arc beneath the central Tarim basin. Our proposed Precambrian magmatic arc would support the suggestion that the Tarim block was once separated by a suture in the Late Proterozoic (Guo et al., 1999). The intervening ocean must have been closed by Cambrian time, when shallow-marine Cambrian strata were deposited over the central Tarim pluton. Similarly, Neoproterozoic passive margine strata resting on top of the southern Tian Shan blueschist and the eastern Altyn Tagh Proterozoic basement indicate that subduction was completed in the Tian Shan by that time. It should be pointed out, however, that there have been no direct geologic observations from the Tarim margin that indicate unambiguously the existence of a Precambrian suture.

It is interesting to note that the suggested Proterozoic arc in the central Tarim basin overlaps with the middle Paleozoic fold belt as expressed by the central Tarim uplift. This uplift can be traced via subsurface data (drill hole and reflection profiles) westward to the Bachu region of the southwestern Tian Shan where it is truncated by the Cenozoic southern Tian Shan thrust belt (Fig. 1). This regional pattern suggests that only the eastern part of the inferred Precambrian arc was reactivated in the middle Paleozoic by contractional deformation. The western
Paleozoic belt departs to the south may have either been initiated entirely as an intracontinental fault zone (Jia et al., 1991) or a Paleozoic suture (Yin and Nie, 1996; cf. Sobel and Arnaud, 1999). The exact relationship between Precambrian structures and Paleozoic deformational belts need further investigation in regions where the two structures overlap. One such place is the central and eastern Altyn Tagh range where both types of plutons are present (Gehrels et al., 2003a; Cowgill et al., 2003). Because the Tarim basement consists of lithologic units correlative with its marginal regions and experienced major contractional deformation in its interior as recent as the Triassic, compositional difference alone cannot be the explanation for the contrasting strain distribution between the Tarim block and Tibet and the Tian Shan in the Cenozoic. Instead, differences in thermal structure or stress magnitude could also explain the contrasting Cenozoic deformational styles across central Asia.

An important question raised by our proposed magmatic arc is the location of its associated suture in and around the Tarim basin. Although, the Aksu blueschist is a good candidate for the suture zone, there is no evidence for its equivalent in northern Tibet are blueschist belts were Cambro-Ordovician in age in the Altyn Tagh range and the Qilian orogenic belt (Liu et al., 1996, 1997; Yang et al., 2001) and may have been offset by the Cenozoic Altyn Tagh fault left laterally for several hundreds of kilometers (Yang et al., 2001). One solution to this problem is that NeoproterozoicCambrian strata rest unconformably above the Proterozoic arc and thus the suture zone in the southern margin of the Tarim basin has been buried below these strata or was rifted away during or immediately prior to deposition of the Neoproterozoic-Cambrian passive continental margin sequence in and around the Tarim basin (Jia, 1997).

Although, the exact polarity of the proposed Precambrian subduction zone cannot be determined with great confidence, some inferences can be made. We note that the Proterozoic granitoids in northern Tibet extend for a considerable distance from the northern margin of the Qaidam basin to the northern Qilian Shan orogen (Gehrels et al., 2003a,b). However, no late Precambrian suture has been reported north of the Qilian Shan where only Archean basement rocks and Paleozoic strata are present. This observation implies that the suture zone must lie south of the Proterozoic arc that might have been rifted away in the latest Precambrian-early Cambrian or severely modified by the middle Paleozoic collisional event. A sketch for this proposed scenario is shown in Fig. 7.

\subsection{Cenozoic tectonics}

Our results from the analyses of central Tarim drill core samples also provide new insights with respect to the role of the Tarim block in the Cenozoic tectonics. Our proposed correlation between the central Tarim pluton and the Precambrian tectonic elements around the 
(a) 970-800 Ma: Arc magmatism and oceanic subduction

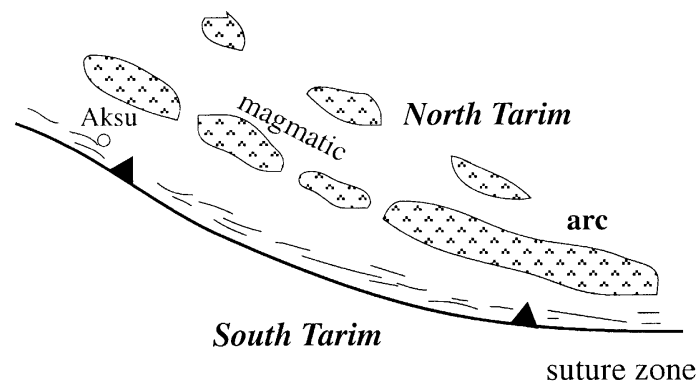

(b) 800-750 Ma: Collision between North and South Tarim

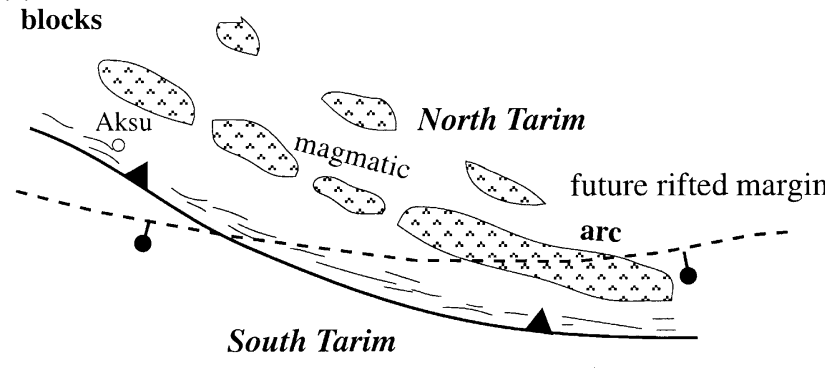

(c) 750-700 Ma: Initiaiton of continental rift

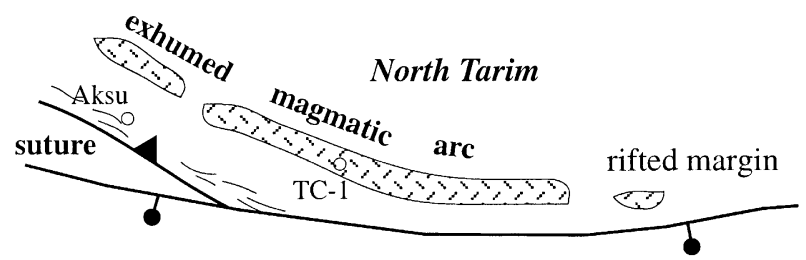

(d) 700-500 Ma: Deposition of a passive continental sequence

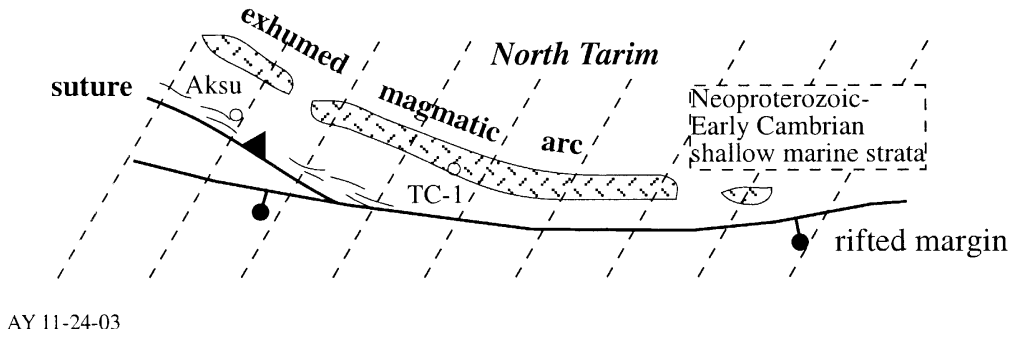

Fig. 7. Proposed tectonic evolution of the central Tarim basin and its surround regions in from late Middle Proterozoic to Early Cambrian. (a) $970-800$ Ma, A Precambrian arc was developed associated with a blueschist belt along the subduction zone. (b) 800-750 Ma, Final closure of the ocean basin as a result of collision between north and south Tarim blocks. (c) 750-700 Ma, Initiation of continental breakup. (d) 700-500 Ma, Deposition of passive continental margin sequence over Tarim and its surrounding regions. Most of the Precambrian arc and blueschist belt are covered by this sequence of sediments.

Tarim basin suggest that the composition of the Tarim basement is not fundamentally different from its surroundings. This implies that the stable domain of the Tarim basin in the Cenozoic may be entirely induced by the arrangement of fault patterns as originally suggested by Molnar and Tapponnier (1975) and
Tapponnier and Molnar (1976). This inference is consistent with the observation that the Tarim basement has experienced significant Phanerozoic deformation, which lasted as late as the Triassic to Early Jurassic (Jia, 1997). Our envisioned process for creating the Cenozoic Tarim basin during the Indo-Asian collision is 


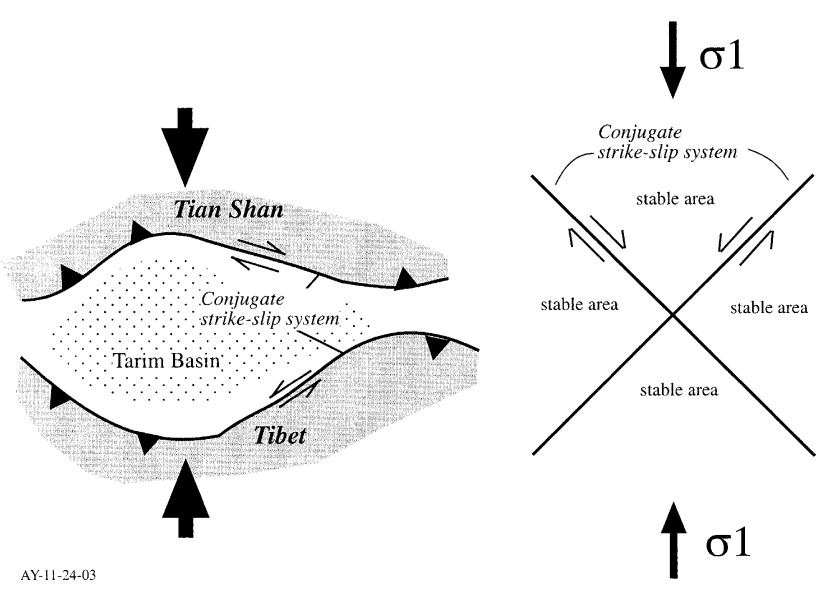

Fig. 8. Cenozoic Tarim basin as a relatively stable block may be a result of the development of a conjugate set of strike-slip faults on its north and south sides of the basin.

shown in Fig. 8, which is modified from Yin and Nie (1996). In essence, this model predicts that the presence of the Tarim basin is resulted from development of a conjugate fault system: the left-slip Altyn Tagh fault and the right-slip central Tian Shan fault system (also see Yin et al., 1998). In addition to the conjugate fault systems in the northwest and southeast of the Tarim basin, the polarity of the Cenozoic thrust belt in the western Kunlun may have played a critical role in preventing deformation fronts from propagating deep into the Tarim interior (Cowgill et al., 2003).

\section{Conclusions}

Geochemical and geochronologic analyses of drill core samples from the basement of the central Tarim basin suggest the possible existence of a Proterozoic magmatic arc that was initiated prior to $790 \mathrm{Ma}$. This arc may be related to the development of a Precambrian blueschist belt in the south-central Tian Shan and a 970-920 Ma granitic belt in the central and eastern Altyn Tagh range. This regional correlation indicates the existence of an east-trending Proterozoic suture zone separating the Tarim into two Precambrian blocks. The presence of Cambrian strata unconformably above the central Tarim pluton and a Noeproterozoic passive margin sequence resting on top of the late Precambrian blueschist belt in the southern Tian Shan suggest that the suture related to the proposed subduction was closed by late Proterozoic to Cambrian time. Our new data do not support early hypotheses that the Tarim block is floored by an remnant oceanic basin or oceanic plateau. Our results also do not favor the proposal that the lack of Cenozoic deformation in the Tarim basin is mainly due to its compositional difference from its neighboring regions. The existence of a Precambrian subduction system and a Proterozoic plutonic belt in and around the Tarim basin may provide additional geologic constraints on reconstructing late Proterozoic supercontinents (Dalziel, 1997; Hoffman, 1999). The next step to understand the basement evolution of the Tarim basin is to determine the mineralogy, geochemical composition, and tectonic setting of the Precambrian plutons around the Tarim basin.

\section{Acknowledgements}

This research was supported by Major State Basic Research Program of People's Republic of China (No. 2001CB409804) and by the Continental Dynamics Program of the US National Science Foundation. We thank J.G. Liou and Mian Liu for very constructive reviews.

\section{References}

Allen, M.B., Vincent, S.J., Wheeler, P.J., 1999. Late Cenozoic tectonics of the Kepingtage thrust zone; interactions of the Tien Shan and Tarim Basin, Northwest China. Tectonics 18, 639-654.

Barbarin, B., 1999. A review of the relationships between granitoid types, their origins and their geodynamic environments. Lithos 46, 605-626.

Briqueu, L., Bougault, H., Joron, J.L., 1984. Quantification of Nb, Ta, Ti, and $\mathrm{V}$ anomalies in magmas associated with subduction zonespetrogenetic implications. Earth Planetary Science Letters 68, 297-308.

Burchfiel, B.C., Brown, E.T., Deng, Q.D., Feng, X.Y., Li, J., Molnar, P., Shi, J.B., Wu, Z.M., You, H.C., 1999. Crustal shortening on the margins of the Tien Shan, Xinjiang, China. International Geology Review 41, $665-700$.

Cebula, G.T., Kunk, M.J., Mehnert, H.H., Naeser, C.W., Obradovich, J.D., Sutter, J.F., 1986. The Fish Canyon Tuff, a potential standard for the ${ }^{40} \mathrm{Ar}-{ }^{39} \mathrm{Ar}$ and fission-track dating methods. Terra Cognita 6, 139-140.

Chen, X.H., Yin, A., George, G.E., Cowgill, E.S., Grove, M., Harrison, T.M., Wang, W.X., 2003. Two phases of Mesozoic north-south extension in the eastern Altyn Tagh Range, northern Tibetan plateau. Tectonics 22(5), 1053

Cowgill, E., Yin, A., Harrison, T.M., Wang, X.F., 2003. Reconstruction of the Altyn Tagh fault based on $\mathrm{U}-\mathrm{Pb}$ geochronology: role of back thrusts, mantle sutures, and heterogeneous crustal strength in forming the Tibetan Plateau. Journal of Geophysical Research 108(B7), 2346.

Dalziel, I.W.D., 1997. Neoproterozoic-Paleozoic geography and tectonics: review, hypothesis, and environmental speculation. Geological Society of America Bulletin 109, 16-42.

Defant, M.J., Drmmont, M.S., 1990. Derivation of some modern arc magmas by melting of young subducted lithosphere. Nature 347, 662-665.

Gao, J., Klemd, R., 2003. Formation of HP-LT rocks and their tectonic implications in the western Tianshan Orogen, NW China: geochemical and age constraints. Lithos 66(1/2), 1-22.

Gao, J., Li, M.S., Xiao, X.C., Tang, Y.Q., He, G.Q., 1998. Paleozoic tectonic evolution of the Tianshan Orogen, northwestern China. Tectonophysics 287, 213-231.

Gehrels, G.E., Yin, A., Wang, X.F., 2003a. Magmatic history of the Altyn Tagh. Nan Shan, and Qilian Shan region of western China. Journal of Geophysical Research 108(B9), 2423. 
Gehrels, G.E., Yin, A., Wang, X.F., 2003b. Detrital-zircon geochronology of the northeastern Tibetan plateau. Geological Society of America Bulletin 115, 881-896.

Guo, Z., Zhang, Z., Wang, J., 1999. Sm-Nd isochron age of ophiolite along northern margin of Altun Tagh Mountain and its tectonic significance. Chinese Science Bulletin 44, 456-458.

Hendrix, M.S., Dumitru, T.A., Graham, S.A., 1994. Late Oligocene-early Miocene unroofing in Chinese Tian Shan: An early effect of the IndiaAsia collision. Geology 22, 487-490.

Hoffman, P.F., 1999. The break-up of Rodinia, birth of Gondwana, true polar wander and the snowball Earth. Journal of African Earth Sciences 28, 17-33.

Hsü, K.J., 1988. Relict back-arc basins: Principles of recognition and possible new examples from China. In: Kleinspehn, K.L., Paola, C. (Eds.), New Perspectives in Basin Analysis, Springer, New York, pp. $245-263$.

Jia, C.Z., 1997. Tectonic characteristics and petroleum, Tarim basin, China, Petroleum Industry Press, Beijing.

Jia, C.Z., Yao, H., Wei, G., Li, L., 1991. Plate tectonic evolution and characteristics of major tectonic units of the Tarim basin. In: Tong, X., Liang, D. (Eds.), The Tarim Basin, Xinjiang Scientific Publishing House, Urumuqi, pp. 207-225, (in Chinese).

Li, D.S., Liang, D.G., Jian, C.Z., Wang, G., Wu, Q.Z., He, D.F., 1996. Hydrocarbon accumulations in the Tarim Basin, China. American Association of Petroleum Geologists 80, 587-1603.

Liou, J.G., Graham, S.A., Maruyama, S., Wang, X., Xiao, X., Carroll, A.R., Chu, J., Feng, Y., Hendrix, M.S., Liang, Y.H., McKnight, C.L., Tang, Y., Wang, Z.X., Zhao, M., Zhu, B., 1989. Proterozoic blueschist belt in western China; best documented Precambrian blueschists in the world. Geology 17, 1127-1131.

Liou, J.G., Graham, S.A., Maruyama, S., Zhang, R.Y., 1996. Characteristics and tectonic significance of the late Proterozoic Aksu blueschists and diabasic dikes, northwest Xinjiang, China. International Geology Review 38, 228-244.

Liu, L., Che, Z.C., Luo, J.H., Wang, Y., Gao, Z.J., 1996. Identification of the eclogite at the west part of Altyn Tagh Mountains and its geologic implications. Chinese Science Bulletin 41, 1485-1488.

Liu, L., Che, Z.C., Luo, J.H., Wang, Y., Gao, Z.J., 1997. Recognition and implications of eclogite at the western Altyn Mountains, Xinjiang. Chinese Science Bulletin 42, 931-934.

McDougall, I., Harrison, T.M., 1999. Geochronology and Thermochronology by the ${ }^{40} \mathrm{Ar} /{ }^{39} \mathrm{Ar}$, second ed., Oxford, New York.

Molnar, P., Tapponnier, P., 1975. Cenozoic tectonics of Asia-the effect of a continental collision. Science 189, 419-426.

Nakajima, T., Maruyama, S., Uchiumi, S., Liou, J.G., Wang, X., Xiao, X., Graham, S.A., 1990. Evidence for late Proterozoic subduction from 700-Myr-old blueschists in China. Nature 346, 263-265.

Neil, E.A., Houseman, G.A., 1997. Geodynamics of the Tarim Basin and the Tian Shan in central Asia. Tectonics 16, 571-584.

Pearce, J.A., Harris, N.B.W., Tindle, A.G., 1984. Trace element discriminaton diagrams for the tectonic interpretation of granitic rocks. Journal of Petrology 25, 956-983.
Renne, P.R., Deino, A.L., Walter, R.C., Turrin, B.D., Swisher, C.C., Becker, T.A., Curtis, G.H., Sharp, W.D., Jaouni, A.R., 1994. Intercalibration of astronomical and radioisotopic time. Geology 22, $783-786$.

Sengör, A.M.C., Graham, S.A., Biddle, K.T., 1996. Is the Tarim basin underlain by a Neoproterozoic oceanic plateau? Geological Society of America Abstracts with Programs 28, 67.

Sobel, E.R., Arnaud, N., 1999. A possible middle Paleozoic suture in the Altyn Tagh, NW China. Tectonics 18, 64-74.

Sobel, E.R., Hilley, G.E., Strecker, M.R., 2003. Formation of internally drained contractional basins by aridity-limited bedrock incision. Journal of Geophysical Research 108(B7), 2344.

Sun, S., McDonough, W.F., 1989. Chemical and isotopic systematics of oceanic basalts: implications for mantle composition and processes. In: Saunders, A.D., Norry, M.J. (Eds.), Magmatism in the Ocean Basins, vol. 42. Geologic Society of London Special Publication, pp. 313-345.

Tapponnier, P., Molnar, P., 1976. Slip-line theory and large-scale continental tectonics. Nature 264, 319-324.

Tian, Z., Chai, G., Kang, Y., 1989. Tectonic evolution of the Tarim Basin. In: Zhu, X., (Ed.), Chinese Sedimentary Basins, Elsevier, Amsterdam, pp. 33-43.

Wang, Q.M., Nishidai, T., Coward, M.P., 1992. The Tarim basin, NW China: formation and aspects of petroleum geology. Journal of Petroleum Geology 15, 5-34.

Xinjiang, B.G.M.R., 1993. Regional Geology of the Xinjiang Uygur Autonomous Region: Beijing, Geological Publishing House.

Yang, Y.Q., Liu, M., 2002. Cenozoic deformation of the Tarim plate and the implications for mountain building in the Tibetan Plateau and the Tian Shan. Tectonics 21(6), 1059.

Yang, J.S., Xu, Z.Q., Zhang, J.X., Chu, J.Y., Zhang, R.Y., Liou, J.G., 2001. Tectonic significance of Early Paleozoic high-pressure rocks in AltunQaidam-Qilian Mountains, NW China. Geological Society of America Memoir 194, 151-170.

Yin, A., Harrison, T.M., 2000. Geologic evolution of the HimalayanTibetan orogen. Annual Review of Earth and Planetary Sciences 28, 211-280.

Yin, A., Nie, S., 1996. A phanerozoic palinspastic reconstruction of China and its neighboring regions. In: Yin, A., Harrison, T.M. (Eds.), Tectonic Evolution of Asia, Cambridge University Press, New York, pp. $442-485$.

Yin, A., Nie, S., Craig, P., Harrison, T.M., Ryerson, F.J., Qian, X., Yang, G., 1998. Late Cenozoic tectonic evolution of the Southern Chinese Tian Shan. Tectonics 17, 1-27.

Yin, A., Rumelhart, P.E., Butler, R., Cowgill, E., Harrison, T.M., Foster, D.A., Ingersoll, R., Qing, Z., Xian-Qiang, Z., Xiao-feng, W., Hanson, A., Raza, A., 2002. Tectonic history of the Altyn Tagh fault system in northern Tibet inferred from Cenozoic sedimentation. Geological Society of America Bulletin 114, 1257-1295.

Zhou, X., Li, Y., Guo, H., Hu, J., Yang, W., Tan, Z., 2002. Stratigraphic section and some discussions of drilling well Tancan 1: the deepest well on-land in China. Chinese Journal of Geology 37, 14-21. 